DOI 10.37882/2223-2982.2020.12-3.09

\title{
ФОРМИРОВАНИЯ МОТИВАЦИИ СТУДЕНТОВ К ЗАНЯТИЯМ ПО ФИЗИЧЕСКОЙ КУЛЬТУРЕ ПОСРЕДСТВОМ ПРИМЕНЕНИЯ ПЕРСПЕКТИВНОЙ ФИЗКУЛЬТУРНО-ОЗДОРОВИТЕЛЬНОЙ ПРОГРАММЫ
}

\section{FORMATION OF STUDENTS' MOTIVATION FOR PHYSICAL CULTURE CLASSES THROUGH THE USE OF A PROMISING PHYSICAL CULTURE AND HEALTH PROGRAM}

R. Garifullin V. Kalmanovich R. Khairullin

Summary: Currently, there is a negative trend of falling interest in sports among students, which negatively affects both the educational process and the health of students. The Deterioration of indicators of physical fitness and health of students makes it necessary to look for new modern technologies and training programs for students at the University. In this paper, it is proposed to use a promising physical training program for conducting physical education classes at a University, which, according to the authors, will increase the motivation of students to engage in sports and physical culture. The implementation of this program will not only motivate students to play sports, but also increase the need for students to take additional physical education and sports, which in turn will reduce the incidence of SARS and other viral infections among students.

Keywords: motivation, physical culture, sports, perspective program, health.

\author{
Гарифуллин Руслан Шамилевич \\ К.т.н., доцент, ФГБОУ ВО «Казанский государственный \\ институт культуры» \\ rus-garifullin@yandex.ru \\ Калманович Владимир Львович \\ К.n.н., дочент, ФГБОУ ВО «Казанский государственный \\ архитектурно-строительный университет» \\ volek71@yandex.ru \\ Хайруллин Рафаэль Равилвич \\ К.п.н., дочент, ФГБОУ ВО «Казанский государственный \\ институт культуры» \\ 89053146495@mail.ru
}

Аннотация: В настоящее время в студенческой среде наблюдается негативная тенденция падения интереса к занятиям спортом, что отрицательно складывается как на учебном процессе, так и на здоровье студентов Ухудшение показателей физической подготовленности и здоровья студентов, заставляет искать новые современные технологии и программы подготовки студентов в вузе. В данной работе предлагается использовать перспективную физкультурно-оздоровительную методику для повышения мотивации студентов к занятиям по физической культуре в вузе. Реализация данной физкультурнооздоровительной программы позволит не только мотивировать студентов к занятиям спортом, но и повысит потребность студентов в дополнительных занятиях физической культурой и спортом, что в Свою очередь позволит снизить заболеваемость студентами ОРВИ и другими вирусными инфекциями.

Ключевые слова: мотивация, физическая культура, спорт, перспективная программа, здоровье.

ставленная возможность выбора занятий по виду спорта подстегнет интерес студентов физической культуре и спорту, повысит их физическую активность и улучшит показатели здоровья студентов. В теории данная идея является привлекательной, так как позволяет учитывать различные предпочтения студентов в занятиях спортом и, в зависимости от их физического, функционального и психологического состояния организма [6].

Однако на практике механизм реализации дисциплины «Элективные курсы по физической культуре и спорту» в вузах России до конца не продуман и имеется ряд проблем связанных с его внедрением. Среди основных проблем можно выделить следующие: каждые вузы имеют разные возможности по материально-технической базе и квалификации профессорско-преподавательского состава, отсутствие четкого механизма сдачи и приема зачетных упражнений по элективным курсам по физической культуре и спорту. Также не ясен принцип 
выбора вида спорта для студентов с отклонениями в состоянии здоровья. Поэтому каждый вуз самостоятельно программу занятий. Поэтому в данной ситуации каждый вуз самостоятельно принимает решение, какие физкультурно-оздоровительные программы применять. В связи с этим разработка и применение перспективной практической программы проведения физической культуры в вузе является актуальной задачей.

Разработанная программа приведена в работе [7], включает упражнения по футболу, волейболу, баскетболу, по настольному теннису, упражнения со скакалкой, с обручем, упражнения по легкой атлетике и гимнастике, а также некоторые комплексы вольных упражнений. В работе приводятся особенности проведения занятий с применением указанных упражнений, описана техника и основные ошибки при выполнении данных упражнений. Особенно ценным является описание методики оценивания выполнения техники приведенных упражнений. Программа разделена на три части: программу упражнений для девушек основной и подготовительной групп, программу упражнений для юношей основной и подготовительной групп и программу упражнений для студентов с отклонениями в состоянии здоровья.

Выполнения данных упражнений не требует сложной материальной базы и высокой квалификации тренеров для демонстрации упражнений. Кроме этого, студенты с незначительными ограничениями по здоровью при должной тренировке смогут освоить технику выполнения упражнений, а также улучшить показатели своего здоровья. Поэтому предложенная программа, по мнению авторов, позволит решить ряд проблем связанных с введением «Элективных курсов по физической культуре и спорту».

Цель исследования: исследовать мотивацию студентов к занятиям по физической культуре и спорту посредством применения новой физкультурно-оздоровительной программы.

Методы исследования: анализ научной литературы, педагогическое тестирование, анкетирование, экспертная оценка, наблюдение, математическая обработка результатов исследований

\section{Методика}

Исследование проводили с первого по четвертый семестр. Для исследований были выбраны юноши первого курса обучения, не имеющие отклонений в состоянии здоровья в количестве 80 человек. Студентов поделили на две группы контрольную и экспериментальную по 40 человек в каждой. Для проверки однородности деления на две группы провели математические исследование, с определением коэффициентом Стьюдента, которое подтвердило, что группы были поделены однородно. Студентам контрольной группы было предложено зани- маться по стандартной методике проведения занятий, а экспериментальной группе - по новой программе.

Для оценки мотивации студентов к занятиям физической культурой по новой оздоровительной программе были выбраны следующие критерии:

- мотивация студентов к занятиям физической культурой и спортом;

- посещаемость занятий по физической культуре и спорта;

- необходимость студентов в дополнительных занятиях физической культурой и спортом;

- оценка заболеваемость студентами ОРВИ и другими вирусными инфекциями.

Оценить мотивацию студентов к занятиям физической культурой является достаточно сложным процессом, поэтому для этих целей использовали опросы, личные беседы, анкетирование. Посещаемость студентами занятий по физической культуре и спорта контролировали в классных журналах посещаемости студентов. Потребность студентов в дополнительных занятиях физической культурой и спортом определяли по их посещаемости спортивных секций, фитнес залов, студенты показывали свои пропускные билеты в спортивную секцию или спортивный клуб. Заболеваемость студентами ОРВИ и другими вирусными инфекциями контролировалась медицинскими справками.

\section{Результаты исследований и их обсужление}

В начале исследования студентов поделили на две группы контрольную и экспериментальную по 40 человек в каждой и изучали однородность их распределения. Для этих целей использовали простейшие тесты по определению физической кондиции студентов. Тесты включали упражнения по подниманию туловища, лежа на спине за 30 сек и сгибанию, и выпрямлению рук в упоре лежа. Результаты исследования приведены в таблицах 1.

Таблица 1

Показатели физической кондиции студентов в контрольной и экспериментальной группах

\begin{tabular}{|l|c|c|}
\hline \multirow{2}{*}{ Сравниваемые группы } & \multicolumn{3}{|c|}{ Показатели физической кондиции } \\
\cline { 2 - 3 } & $\begin{array}{c}\text { Поднимание тулови- } \\
\text { ща, лежа на спине 3а } \\
30 \text { сек, раз, } \mathrm{n}=40\end{array}$ & $\begin{array}{c}\text { Сгибание и выпрямле- } \\
\text { ние рук в упоре лежа, } \\
\text { раз, } \mathrm{n}=40\end{array}$ \\
\hline$Э Г,(\mathrm{M} \pm \mathrm{m})$ & $35 \pm 2,6$ & $38 \pm 3,1$ \\
\hline $\mathrm{K},(\mathrm{M} \pm \mathrm{m})$ & $37 \pm 2,9$ & $36 \pm 3,4$ \\
\hline Критерий Стьюдента & $1,4^{*}$ & $1,72^{*}$ \\
\hline
\end{tabular}

Примечание: *- достоверно при $(P>0,05)$,

Из данных, представленных, в таблице 1 видно, что по результатам двух тестом полученные значения для двух КГ и ЭГ групп отличаются незначительно. Для оценки 
Сравнительные результаты оценки мотивации студентов к занятиям физической культуре для КГ и ЭГ групп в I и IV семестрах обучения

\begin{tabular}{|c|c|c|c|c|c|c|c|c|}
\hline \multirow{3}{*}{$\begin{array}{l}\text { Сравнивае- } \\
\text { мые группы }\end{array}$} & \multicolumn{8}{|c|}{ Сравниваемые показатели мотивации студентов к занятиям по физической культуре и спорту, N=80 } \\
\hline & \multicolumn{2}{|c|}{$\begin{array}{c}\text { Мотивация студентов к за- } \\
\text { нятиям физической культурой } \\
\text { и спортом }\end{array}$} & \multicolumn{2}{|c|}{$\begin{array}{c}\text { Посещаемость студентами за- } \\
\text { нятий по физической культуре } \\
\text { и спорта }\end{array}$} & \multicolumn{2}{|c|}{$\begin{array}{c}\text { Потребность студентов в } \\
\text { дополнительных занятиях } \\
\text { физической культурой } \\
\end{array}$} & \multicolumn{2}{|c|}{$\begin{array}{c}\text { Заболеваемость студентов } \\
\text { ОРВИ и другими вирусными } \\
\text { инфекциями. } \\
\end{array}$} \\
\hline & I семестр & IV семестр & I семестр & IV семестр & I семестр & IV семестр & I семестр & IV семестр \\
\hline$Э \Gamma, \%$ & 69 & 89 & 78 & 95 & 60 & 90 & 26 & 9 \\
\hline $\mathrm{K} \Gamma, \%$ & 65 & 76 & 79 & 85 & 56 & 76 & 25 & 18 \\
\hline
\end{tabular}

однородного распределения студентов по группам рассчитывали критерий Стьюдента, для уровня значимости, равного 0,05 и числа степеней свободы системы, равной 78. Затем проводили сравнение табличных и расчетных критериев Стьюдента, и установили, что расчетные значения меньше табличных. В соответствии с этим сделали вывод, что студенты в начальной точке эксперимента в КГ и ЭГ группах распределены однородно.

После этого начиная с первого семестра по четвертый студенты контрольной группы занимались физической подготовкой по стандартной методике, а студенты экспериментальной группы - по новой перспективной физкультурно-оздоровительной программе проведения практических занятий в вузе. После окончания эксперимента сравнивали полученные данные и делали выводы. Результаты исследований оценки мотивации студентов к занятиям физической культуре для КГ и ЭГ групп в I и IV семестрах обучения приведены таблице 2.

Из данных представленных в таблице 2 видно, что улучшение сравниваемых показателей с I по IV семестр произошли как в контрольной, так и в эксперименталь- ной группах. При этом рост показателей в экспериментальной группе по сравнению с контрольной группой оказался значительно выше, а заболеваемость значительно ниже. В частности, по мотивации студентов к занятиям физической культурой и спортом в ЭГ по сравнению с КГ рост составил 13\%, посещаемость студентами занятий по физической культуре и спорту выросла на 10\%, потребность студентов в дополнительных занятиях физической культурой и спортом выросла на 14\%, при этом заболеваемость студентами ОРВИ и другими вирусными инфекциями в ЭГ по сравнению с КГ снизилась в 2 раза.

\section{Выводы}

Применение новой перспективной программы в учебном процессе позволяет повысить интерес студентов к занятиям физической культурой и спортом, значительно повысить их двигательную активность и улучшить исследуемые показатели мотивации, при этом следует отметить, что у студентов значительно снизилась заболеваемость вирусными инфекциями.

\section{ЛИТЕРАТУРА}

1. Актуальные проблемы развития физического воспитания студентов / Н.Т. Канагатов, Л.А. Сирока // Материалы IV международной научно-практической конференции «0бразование: традиции и инновации», 2014. - С. 60-63.

2. Актуальные проблемы физического воспитания студентов / А.В. Бажин, Е.О. Дрягина // Материалы VIII международной научно-практической конференции «Современное образование: плюсы, минусы и перспективы», 2017. - С. 18-21.

3. Лубышева Л.И. Концепция физкультурного воспитания: методология развития и технология реализации / Л.И. Лубышева // Физическая культура: воспитание, образование, тренировка. - 1996. - №1. - С. 11-17.

4. Рязанова Е.А. Организация физической культуры для студентов с ослабленным здоровьем в вузе / Е.А. Рязанова, Л.А. Гиренко // Материалы VII Международной научно-практической конференции «Современные образовательные технологии в мировом учебно-воспитательном пространстве», 2017. - С. 124-128.

5. Физическая подготовленность студенческой молодежи как фактор успешности в будующей профессиональной деятельности / А.А. Болотников, В.Л. Калманович, Э.Р. Мугаттарова и др. // European Social Science Journal. - 2017. - №9. - C.244-248.

6. Коршунова 0.С. Элективные курсы по физическому воспитанию в вузах, перспективы и возможности / О.С. Коршунова, Л.Н. Роледер. // Молодой ученый. - 2016. - № 23 - С. 558-560.

7. Зенуков И.А. Методические рекомендации по проведению занятий по физической культуре в ФГБОУ В0 «КНИТУ» : учебно-методическое пособие / И.А. Зенуков, Р.Ш. Гарифуллин - Казань. нац. технол. ун-т. - Казань: Издательство «ФЭН» Академии наук РТ, 2019. - 208 с. 